\title{
Intestinal Contents of a Late Pleistocene Mastodont from Midcontinental North America
}

\author{
BRADLEY T. LEPPER \\ Newark Earthworks State Memorials, The Ohio Historical Society, 99 Cooper Avenue, Newark, Ohio 43055 \\ Tod A. Frolking \\ Department of Geology and Geography, Denison University, Granville, Ohio 43023 \\ Daniel C. Fisher \\ Museum of Paleontology, University of Michigan. Ann Arbor, Michigan 48109 \\ Gerald Goldstein and Jon E. Sanger \\ Department of Botany/Microbiology, Ohio Wesleyan University, Delaware, Ohio 43105 \\ DeE ANNE WyMER \\ Department of Anthropology, Bloamsburg University, Bloomsburg, Pennsylvania 17815 \\ J. GoRdon OGDEN III \\ Department of Biology, Dalhousie University, Halifax, Nova Scotia, Canada B3H 2A2
}

AND

Paul E. Hooge

Licking County Archueology and Landmarks Society, Newark, Ohio 43055

Received March 3, 1991

\begin{abstract}
Salvage excavations of a nearly complete and remarkably well-preserved skeleton of an American mastodont (Mammut americanum) in Licking County, Ohio, yielded a discrete, cylindrical mass of plant material found in association with articulated vertebrae and associated ribs. This material is interpreted as intestinal contents of the mastodont and paleobotanical analyses indicate that the mastodont diet included significant amounts of low, herbaceous vegetation. Enteric bacteria (Enterobacter cloacae), isolated from a sample of this material, are believed to represent survivors or descendants of the intestinal microflora of the mastodont. This is the first report of the isolation of bacteria associated with late Pleistocene megafauna. 1991 University of Washington.
\end{abstract}

\section{INTRODUCTION}

Explanations of late Pleistocene megafaunal extinctions depend, in large measure, on ecological data for the various species involved. Dietary evidence, especially, must be an integral component of any comprehensive understanding of the extinction process. For some taxa, such as mammoths (Mammuthus sp.), there is good evidence for diet, including dessicated dung balls
(Davis et al., 1984) and gut contents of carcasses preserved in permafrost (Vereshchagin and Baryshnikov, 1984). For mastodonts (Mammut americanum), dietary evidence is meager. There are reports of masses of plant material associated with mastodont skeletons in peat (e.g., Warren, 1852; Garland and Cogswell, 1985; Laub, $1990 ;$ R. W. Graham, personal communication, 1990); however, there has been little published analysis of such material. This 
paper reports the occurrence of mastodont intestinal contents recovered in primary context and identified on the basis of multiple lines of evidence, some of which are adduced here for the first time.

The Burning Tree mastodont was uncovered in December 1989, during mechanical excavation of a small pond for a golf course in Licking County, Ohio (Fig. 1). The bones of this individual occurred within fibric and hemic peat (Fig. 2) in a small ( $<0.5$ ha) wetland on a gently undulating late-Wisconsinan end moraine ( $\mathrm{N} 39^{\circ} 58^{\prime} 45^{\prime \prime}$ lat., W $82^{\circ} 27^{\prime} 10^{\prime \prime}$ long.). Retention of many articular relationships (Fig. 2) indicates that soft tissue was present when the bones were introduced into the shallow-water sediments; however, displacement of sets of articulated elements relative to one another indicates some postmortem disturbance of the carcass. The skeleton is complete except for both thyrohyoids, most phalanges and sesamoids, the left patella, the right femur, tibia, and fibula, and all but two (ca. tenth and fourteenth, out of about 24) caudal vertebrae posterior to the eighth. The bones of the mastodont are in pristine condition, with no evidence of subaerial weathering and few unambiguous indications of damage by carnivores or scavengers. Tusk dimensions, state of skeletal development, and state of molar eruption and wear (Laws' relative age class XIX; Laws, 1966) suggest that this is an almost fully grown malc.

Two 3.6-m sediment cores were taken through the organic and clastic lake deposits to the underlying till. The organic sediments are dominated by autochthonous materials rich in sedimentary pigments. Low iron to manganese ratios, bands of ferrous sulfide, and high carotenoid levels indicate

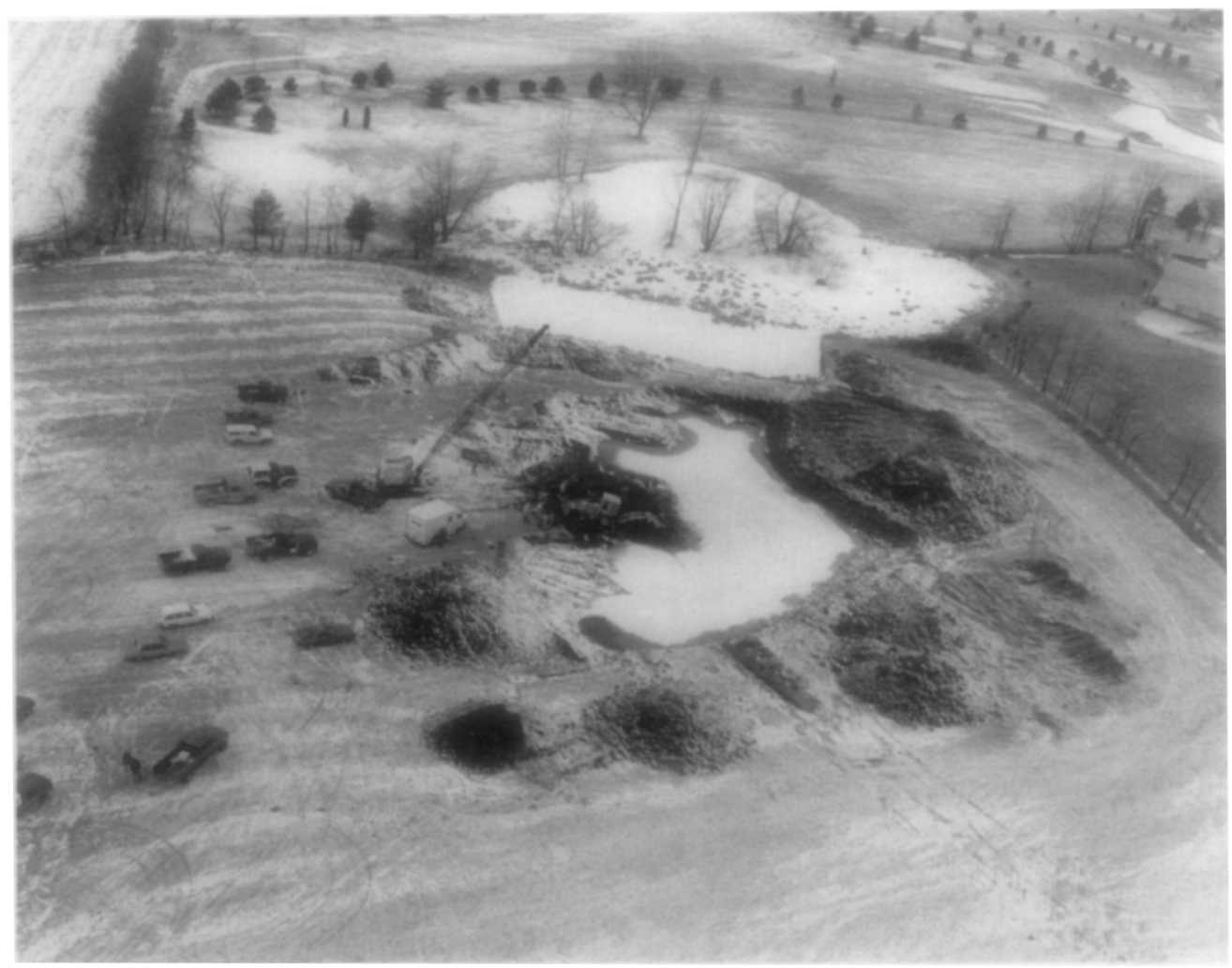

FIG. 1. Aerial view of the Burning Tree mastodont site, Licking County, Ohio, on December 14, 1989. The mastodont was recovered from the dark area in the center of the photograph, behind and beneath the extended arm of the backhoe. 


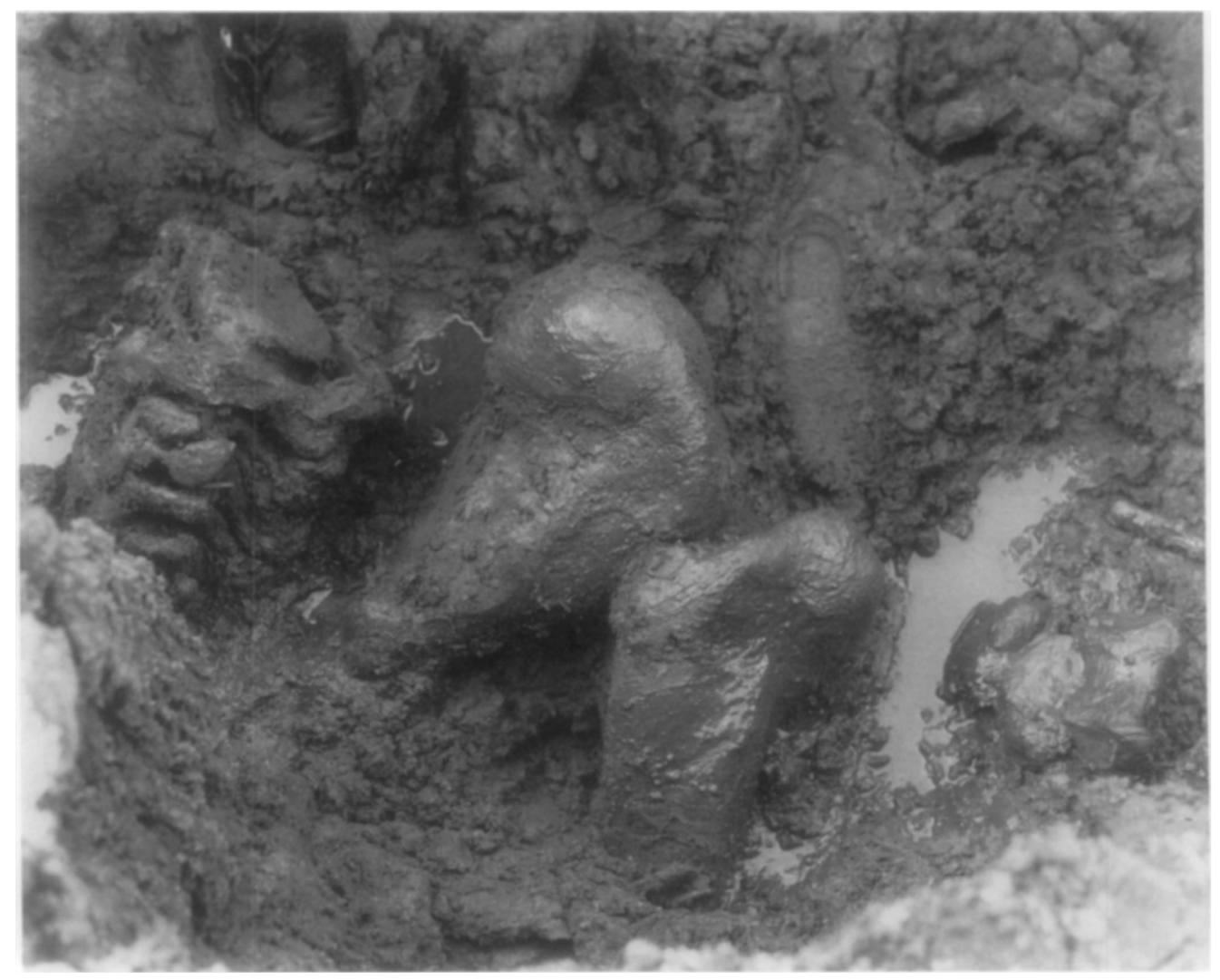

Fig. 2. Mastodont bones in situ showing articulated cervical vertebrae, two humeri, and semiarticulated foot bones. A scale is provided by the boot print which is approximately $30 \mathrm{~cm}$ long.

a strongly anaerobic environment throughout the period of basin filling. Littoral and planktonic diatoms are common as well as shallow water copepods and cladocerans. The pollen profile for the entire core sequence is dominated by spruce (Picea), fir (Abies), and pine (Pinus) pollen characteristic of late-glacial and early postglacial forests at the southern margin of the Wisconsinan ice sheets in midcontinental North America (Shane, 1987; Watts, 1983).

\section{ANALYSIS OF INTESTINAL CONTENTS}

During the excavation of some of the ribs and associated thoracic vertebrae, excavators noted an elongate mass of organic material (ca. $60 \times 12 \mathrm{~cm}$ ) distinguished from the surrounding dark brown peat by its reddish-brown color and pungent odor. Due to its location and distinctive properties this material was provisionally identified as gut contents. During sampling the material separated cleanly from the surrounding peat leaving a cylindrical impression in the matrix. Samples of this gut material and adjacent peat differ markedly in floral composition. The gut sample has a larger proportion of unidentified, highly fragmented florets (spike or raceme), possibly of a swamp grass, along with a matted mass of leaves, moss (including Calliergon sp.) and nonconiferous twigs. These twigs are small (mean length $=20 \mathrm{~mm}, \mathrm{SD}=6 \mathrm{~mm}, N=14$ ) and most lack bark and exhibit sheared ends. The peat sample consists of many amorphous plant materials including twigs of widely varying sizes (conifer as well as deciduous), rootlets, portions of leaves (both small, narrow monocot leaves and fragments of veined dicot leaves), small plant stem parts, small to medium siced (1-3 mm) fragments of wood charcoal (notably absent 
in the gut sample), and a small number of florets similar to those found in the gut sample.

Seeds are abundant in both samples, but they constitute a much lower proportion of the gut sample. In addition, the percentages of various taxa were quite distinct. The gut sample includes an abundance of small (1 $\mathrm{mm}$ diameter) seeds tentatively identified as clover (Trifolium?), as well as sedges (Carex sp., C. crawei, C. hystericina, and Cladium mariscoides) and naiads (Najas flexilis and $N$. sp.) with lesser amounts of pondweed (Potamogeton sp.), waterlily (Nymphaea tuberosa), and pigweed (Amaranthus sp.). In contrast, the peat sample was dominated by thousands of naiad seeds (Najas flexilis) and a greater variety of other species including pondweeds (Potamogeton natans?, $P$. diversifolius?, and $P$. spirillus?), sedges (Carex comosa?, $C$. awuatilis?, and C. sp.), waterlily ( $\mathrm{Nym}$ phaea tuberosa), marsh St.-John's wort (Hypericum virginicum var. Fraseri), spikerush (Eleocharis sp.), rush (Juncus sp.), burreed (Sparaganium chorocarpum?), flatsedge (Cyperus sp.), and an unidentified carbonized seed.

All of the plant species represented in the gut sample by seeds flower in midsummer and set seed by late summer to early autumn indicating an early autumn death for the mastodont. Analysis of incremental lamination in tusk dentin, following methods described by Fisher (1988), confirms this inference.

Pollen grains recovered from interstices on the occlusal surfaces of the molar dentition provide independent dietary information. Although pollen and other particulate matter may have been introduced anytime between the eruption of the tooth and the excavation of the skeleton, it seems likely that such materials would have accumulated during the mastication of plant matter. Cementum was removed from the third molars and additional material was scraped from cavities in the dentine of the second molars. Pollen grains were recovered by (1) digestion with $10 \% \mathrm{HCl}$, (2) extraction with
$70 \%$ alcohol, (3) digestion with warm $10 \%$ $\mathrm{KOH}$, and (4) subsequent isolation by standard treatment for peat samples.

The yield of pollen was understandably meager; only 68 pollen grains were recovered from $25 \mathrm{~g}$ of material. Herbaceous species, particularly sedges, grasses, and aquatic plants, account for $62 \%$ of the pollen assemblagc. In addition, small numbers of moss and sphagnum spores were recovered. While perhaps not a direct reflection of diet, this pollen spectrum differs significantly from baseline regional pollen spectra, which show an overwhelming predominance of spruce, fir, and pine for this time period, with a nonarboreal component of less than $10 \%$ (e.g., C. J. Woltemade, unpublished data).

\section{RADIOCARBON AGE}

Radiocarbon analysis of bone collagen from the mastodont yielded an age of $10,860 \pm 70$ yr B.P. (Pitt-0830; Table 1); however, bone collagen dates typically are younger than dates from other organic materials (Meltzer and Mead, 1983, p. 132; R. Stuckenrath, personal communication, 1990). Dates of $11,660 \pm 120 \mathrm{yr}$ B.P. (Beta38241/ETH-6758) and $11,450 \pm 70$ уг B.P. (Pitt-0832) were obtained from nonconiferous twigs and other organic matter from the presumed gut contents, and these statistically equivalent dates should provide a more accurate age of the mastodont. Large twigs and branches of spruce recovered in association with the skeleton yield dates which are up to $1000 \mathrm{yr}$ older, indicating that the skeleton sank into older deposits.

\section{BACTERIOLOGICAL ANALYSIS}

To evaluate further the properties of the material provisionally identified as gut contents, a bacteriological investigation was undertaken. Samples of peat and gut material were inoculated into sterile tryptoneyeast extract-glucose broth and sterile thioglycollate broth. After incubation overnight, the samples were turbid, indicating bacterial growth. The broth cultures werc streaked onto nutrient agar plates and 
Table 1. Radiocarbon ages for the Burning Tree Mastodont Site, licking County, Ohio

\begin{tabular}{|c|c|c|c|c|}
\hline $\begin{array}{l}\text { Sample } \\
\text { No. }\end{array}$ & Material & Context & $\begin{array}{c}\text { Age } \\
\text { (yr B.P.) }\end{array}$ & $\begin{array}{c}\text { Laboratory } \\
\text { No. }\end{array}$ \\
\hline BTM-002 & Spruce wood & $\begin{array}{l}\text { Associated with } \\
\text { skeleton }\end{array}$ & $12,620 \pm 90$ & Beta-35046 \\
\hline BTM-006 & Peat, soil & $\begin{array}{l}\text { Associated with } \\
\text { skeleton }\end{array}$ & $12,230 \pm 70$ & Pitt-0833 \\
\hline ВТМ-001 & Spruce wood & $\begin{array}{l}\text { Associated with } \\
\text { skeleton }\end{array}$ & $11,720 \pm 110$ & Beta-35045 \\
\hline BTM-003 & Twigs & Gut contents & $11,660 \pm 120$ & $\begin{array}{r}\text { Beta-38241/ } \\
\text { ETH-6758 }\end{array}$ \\
\hline BTM-004 & Organics & Gut contents & $11,450 \pm 70$ & Pitt-0832 \\
\hline ВТM-007 & $\begin{array}{l}\text { Beaver gnawed } \\
\text { wood }\end{array}$ & & $11,470 \pm 90$ & Pitt-0841 \\
\hline B'TM-005 & $\begin{array}{l}\text { Bone, collagen } \\
\text { fraction }\end{array}$ & & $10,860 \pm 70$ & Pitt-0830 \\
\hline
\end{tabular}

blood agar plates and incubated aerobically and anaerobically. The colonies of bacteria incubated anaerobically all proved to be facultative anaerobes. No strict anaerobes were found on any of the bacteriological media inoculated.

Two colony types of gram-negative bacilli were isolated from the gut sample and identified as Enterobacter cloacae. Enterobacter species occur naturally in soil and water (Stanier et al., 1976), but E. cloacae is the most common member of the genus found in the intestinal tracts of animals (Krieg, 1984).

As a control for our observations on the gut sample, a similar series of tests was run on samples of adjacent peat. Two different strains of gram-negative bacteria were isolated from the peat samples: Serratia fonticola, which is found in streams and freshwater environments (Krieg, 1984), and Citrobacter freundii, which commonly occurs in soil and water, though it also may be found in the intestinal tract of animals (Kricg, 1984). E. cloacae was not isolated from the peat samples. The peat thus contains bacterial taxa that might be expected, independent of the occurrence of a large mammal carcass, whereas the presumed gut material includes a form that is absent in the surrounding peat and that is frequently encountered in animal intestinal tracts. We therefore conclude that the culture obtained from the gut sample is most likely derived from survivors or possibly descendants of the intestinal microflora of the mastodont.

\section{DISCUSSION}

The biogeochemical circumstances which promoted excellent preservation of the mastodont skeleton and gut material within the intestines also allowed gut bacteria to persist for $11,000 \mathrm{yr}$. We believe this is the first report of the isolation of enteric bacteria from late Pleistocene megafauna. Molecular biological comparisons between these bacteria and modern members of the same species will have important implications for the study of evolutionary change in these groups.

As was noted above, there have been other claims in the literature for the recovery of gut contents from American mastodonts (reviewed by Dreimanis, 1968). In several of these cases, gut contents have comprised morphologically discrete masses, but the Burning Tree mastodont gut material is thus far unique in offering evidence of (1) a floral composition that contrasts with that of the surrounding matrix but (2) is compatible with pollen removed from the dentition, (3) a scason of death determined from inferred food remains that is confirmed by analysis of tusk laminations, and (4) a bacterial flora that corroborates the hypothesis of an enteric 
source. Therefore, this appears to constitute the most definitive identification of mastodont gastrointestinal contents.

Mastodonts have been characterized as predominantly browsing animals (Martin and Guilday, 1967), and most previous accounts of gut contents have identified coniferous twigs as a dominant element in their diet (Dreimanis, 1968; Garland and Cogswell, 1985; Laub, 1990). In contrast, intestinal contents of the Burning Tree mastodont are notable for their nonconiferous nature and their inclusion of components suggestive of selective feeding on low, herbaceous vegetation, implying a mixture of browsing and grazing habits. Although generalization from this sample may be premature, the central role played by diet in at least some hypotheses for mastodont extinction (Dreimanis, 1967; Graham and Lundelius, 1984; King and Saunders, 1984) gives such results profound importance for evaluating the overall pattern of late Pleistocene megafaunal extinction.

\section{ACKNOWLEDGMENTS}

The recovery of the Burning Tree mastodont was accomplished through the efforts of the Licking County Archaeology and Landmarks Society in cooperation with Sherman Byers. Flowers Excavating Company, and the Licking County Joint Vocational School. Howard Crum and Anthony Reznicek, University of Michigan, David Johnson, Ohio Wesleyan University, and Jan Janssens, University of Minnesota, assisted with some of the plant identifications. Michael Hansen, Ohio Department of Natural Resources, and J. Tiedje, Michigan State University, read early drafts of this manuscript and offered helpful suggestions.

\section{REFERENCES}

Davis, O. K., Agenbroad, L., Martin, P. S., and Mead, J. I. (1984). The Pleistocene dung blanket of Bechan Cave, Utah. In "Contributions in Quaternary Vertebrate Paleontology" (H. H. Genoways and M. R. Dawson, Eds.), pp. 267-282. Carnegie Museum of Natural History Special Publication No. 8, Pittsburgh, PA.

Dreimanis, A. (1967). Mastodons, geologic age, and extinction in Ontario. Canadian Journal of Earth Sciences 4, 663-675.

Dreimanis, A. (1968). Extinction of mastodons in eastern North America: Testing a new climaticenvironmental hypothesis. Ohio Journal of Science 68, 257-272.

Fisher, D. C. (1988). Season of death of the Hiscock mastodonts. Bulletin of the Buffalo Society of Natural Sciences 33, 115-125.

Garland, E., and Cogswell, J. (1985). The Powers mastodon site, Van Buren County, Michigan. Michigan Archeologist 31, 3-39.

Graham, R. W. and Lundelius, E. L., Jr. (1984). Coevolutionary disequilibrium and Pleistocene extinctions. In "Quaternary Extinctions" (P. S. Martin and R. G. Klein. Eds.), pp. 223-249. Univ. of Arizona Press, Tucson.

King, J. E. and Saunders, J. J. (1984). Environmental insularity and the extinction of the American mastodont. In "Quaternary Extinctions" (P. S. Martin and R. G. Klein, Eds.), pp. 315-339. Univ. of Arizona Press, Tucson.

Kreig, N. (Ed.), (1984). 'Bergey's Manual of Systematic Bacteriology." Williams \& Wilkins, Baltimore.

Laub, R. S. (1990). The Hiscock site (western New York): Recent developments of Pleistocene and early Holocene interest. Current Research in the Pleistocene 7, 116-118.

Laws, R. M. (1966). Age criteria for the African elephant, Loxodonta africana. East African Wildlife Journal 4, 1-37.

Martin, P. S., and Guilday, J. E. (1967). A bestiary for Pleistocene biologists. In "Pleistocene Extinctions" (P. S. Martin and H. E. Wright, Jr., Eds.), pp. 1-62. Yale Univ. Press, New Haven, CT.

Meltzer, D. J. and Mead, J. I. (1983). The timing of late Pleistocene mammalian extinctions in North America. Quaternary Research 19, 130-135.

Shane, L. C. K. (1987). Late-glacial and climatic history of the Allegheny Plateau and the Till Plains of Ohio and Indiana, U.S.A. Boreas 16, 1-20.

Stanier, R. Y., Adleberg, E. A., and Ingraham, J. (1976). "The Microbial World," 4th ed. PrenticeHall, Englewood Cliffs, NJ.

Vereschchagin, N. K., and Baryshnikov, G. F. (1984). Quaternary mammalian extinctions in northern Eurasia. In "Quaternary Extinctions" (P. S. Martin and R. G. Klein, Eds.), pp. 483-516. Univ. of Arizona Press, Tucson.

Warren, J. C. (1852). "Description of a Skeleton of the Mastodon giganteus of North America." Wilson \& Son, Boston.

Watts, W. A. (1983). Vegetational history of the eastern United States 25,000 to 10,000 years ago. In "Late Quaternary Environments of the United States, Volume 1," (S. C. Porter, Ed.), pp. 294-310. Univ. of Minnesota Press, Minneapolis. 